\title{
PHYSIQUE AND OCCUPATION OF MEN ADMITTED TO MENTAL HOSPITALS
}

\author{
BY \\ R. W. PARNELL \\ External Scientific Staff of the Medical Research Council \\ AND \\ H. C. A. SOMERSET \\ With a grant from the Medical Research Council
}

In sociomedical studies, and more especially now that infectious diseases have declined, greater attention is being directed to the personal qualities and characteristics that are associated with greater disposition to illness. Physique is one of these qualities and it has the advantage of being measurable. Anthropometry can provide in fact a useful lever into the complex reasons why particular individuals choose particular occupations; and also why particular consequences may follow the adoption of, say, an active or sedentary occupation. If muscularity contributes to self-selection for manual and active occupations, and if sedentary occupations predispose to obesity, it might be thought appropriate to measure such physical qualities directly. These measures need not replace traditional measures of body size employing height and weight, but by laying greater emphasis on body shape and content they may be found to correlate more closely with physiological function and behaviour. Social class and other group discrepancies in height and weight, so often attributed to environmental influence, do not necessarily result from such factors alone (Parnell, 1954), and in so far as constitutional variation is genetically determined the data to be presented here should add something of value to both our knowledge and understanding.

\section{SAMPLE}

The men who compose the sample $(1,488)$ were patients admitted to the four mental hospitals in the southern part of the Oxford region during the years 1955 to 1959. It did not prove practical to measure every single male patient, but the method adopted of visiting each hospital weekly and measuring men admitted since the previous week, made the sample as nearly representative of all admissions as possible. Very short-stay patients admitted after one visit and discharged before the next week's visit were missed; so too were a very small number who refused to be seen. In addition to the physical measurements, all of which were taken by one of the authors (R.W.P.), Dr. Ian Skottowe, consultant psychiatrist, examined all the subjects, using a standard record form of mental examination specially designed for this pur pose. The diagnoses referred to in the text are therefore those made by a single observer.

\section{MeAsurements}

The measurements taken include the following:

(i) Skinfold thickness, mainly subcutaneous fat, over the back of the arm, over the scapular, and in the supra-iliac region.

(ii) Measurements of muscularity:

(a) Transverse width of bones, namely the bicondylar widths of humerus and femur.

(b) Limb girth over the biceps and calf muscles.

(iii) Ponderal index (height divided by the cube root of weight), to provide a measure of the linearity of body build.

From these three groups of measurements a threenumeral index was derived on the lines of the somatotype index of Sheldon, Stevens, and Tucker (1940), although Sheldon's estimates were of course based on photoscopic assessment. The index will be referred to here as "the phenotype", because of the important differences in the method of deriving it by means of physical anthropometry, and also because it seems unnecessary to insist, at least in the present 
context, on Sheldon's definition of somatotype that it is the best estimate of morphogenetic endowment. The final phenotype ratings were based on the M4 deviation chart, modified occasionally to a slight degree if prominent evidence of dysplasia could be seen in standard three-view photographs. Fuller details of the M4 chart, and present technique have been described by Parnell (1958).

The three components of the index will be spoken of as Fat, Muscularity, and Linearity of build, and the six dominances of physique are defined in the order of the relevant numerals in the index thus:

\begin{tabular}{|c|c|c|c|}
\hline Code & $\begin{array}{c}\text { Phenotype } \\
\text { Example }\end{array}$ & $\begin{array}{c}\text { Primary } \\
\text { Dominance }\end{array}$ & $\begin{array}{l}\text { Secondary } \\
\text { Dominance }\end{array}$ \\
\hline $\begin{array}{l}\text { Fl } \\
\text { Fm } \\
\text { Mf } \\
\text { Ml } \\
\text { Lm } \\
\text { Lf }\end{array}$ & $\begin{array}{l}523 \\
532 \\
352 \\
253 \\
235 \\
325\end{array}$ & $\begin{array}{c}\text { Fat } \\
\text { Fat } \\
\text { Muscularity } \\
\text { Muscularity } \\
\text { Linearity } \\
\text { Linearity }\end{array}$ & $\begin{array}{c}\text { Linearity } \\
\text { Muscularity } \\
\text { Fat } \\
\text { Linearity } \\
\text { Muscularity } \\
\text { Fat }\end{array}$ \\
\hline
\end{tabular}

\section{Results}

Table I gives the percentage of patients belonging to each phenotype dominance according to their stated occupation. Occupations are classified by the Registrar General's code numbers 01 to 100 (Mental Health Supplement, 1952-53) and all those are included where the sample exceeded thirty. A com- parative ratio is added for the reader to see at a glance those kinds of physique which are more or less common than would be expected from the sample as a whole. It is defined as follows:

\section{Comparative Ratio $=$ \\ Percentage Phenotype in Particular Occupation \\ Percentage of Phenotype in All Occupations $\times 100$.}

Expectation therefore equals 100 . A comparative ratio (C.R.) of 200 indicates that there are twice as many men of that particular occupation and phenotype dominance as would be expected from the phenotype distribution of the total sample, while correspondingly a comparative ratio of 50 would indicate that the observed frequency was only half the expected frequency.

For each occupational group, the significance of the total pattern of variation in the comparative ratios between the phenotype dominances was determined, using the $\chi^{2}$ test with three, four, or five degrees of freedom. When this total variation was significant at the 95 per cent. level or better, the significance of individual comparative ratios was assessed, using $\chi^{2}$ with one degree of freedom. The results of these tests are included in Table $I$.

\section{Phenotype Dominance}

Ten of the twelve occupational groups show a greater degree of variation in their phenotype distributions than might have been expected by chance,

TABLE I

DISTRIBUTION OF PHENOTYPE DOMINANCE BY OCCUPATION

\begin{tabular}{|c|c|c|c|c|c|c|c|c|c|c|c|c|c|c|c|c|c|c|c|c|c|}
\hline Occupation & $\begin{array}{c}\text { No. } \\
\text { of } \\
\text { Cases }\end{array}$ & \multicolumn{6}{|c|}{ Percentages } & \multicolumn{6}{|c|}{ Comparative Ratios } & \multicolumn{2}{|c|}{$\begin{array}{c}\text { Overall } \\
\text { Variation }\end{array}$} & \multicolumn{6}{|c|}{$\begin{array}{l}\text { Individual C.R.s, where } \\
\text { Appropriate (per cent.) }\end{array}$} \\
\hline $\begin{array}{l}\text { Finance and Public Ad- } \\
\text { ministration (Fig. 1) } \\
\text { Scientists (Fig. 2) } \\
\text { Farmers and Skilled Agri- } \\
\text { culturalists } \\
\text { Skilled Metal and Ėlectrical }\end{array}$ & $\begin{array}{l}38 \\
36 \\
40\end{array}$ & $\left|\begin{array}{l}13 \cdot 2 \\
19 \cdot 4\end{array}\right|$ & $\begin{array}{r}13 \cdot 2 \\
8 \cdot 3\end{array}$ & $21 \cdot 0$ & $21 \cdot 0$ & $\left|\begin{array}{r}18 \cdot 4 \\
2 \cdot 8 \\
2 \cdot 5\end{array}\right|$ & $\begin{array}{c}13 \cdot 2 \\
13 \cdot 9 \\
12 \cdot 5\end{array}$ & $\begin{array}{r}76 \\
112 \\
145\end{array}$ & $\begin{array}{r}55 \\
34 \\
114\end{array}$ & $\begin{array}{r}73 \\
107 \\
73\end{array}$ & $\begin{array}{l}151 \\
180 \\
108\end{array}$ & $\begin{array}{r}307 \\
47 \\
42\end{array}$ & $\begin{array}{l}131 \\
138 \\
124\end{array}$ & $\begin{array}{l}4 \\
4 \\
4\end{array}$ & $\begin{array}{l}95 \\
90 \\
50\end{array}$ & $\mid \begin{array}{c}\text { N.S. } \\
-\end{array}$ & $\begin{array}{l}\text { N.S. } \\
-\end{array}$ & $\begin{array}{l}\text { N.S. } \\
-\end{array}$ & $\mid \begin{array}{c}\text { N.S. } \\
-\end{array}$ & $\begin{array}{r}98 \\
-1 \\
-\end{array}$ & $\left.\right|_{-} ^{8}$ \\
\hline \begin{tabular}{lcc}
\multicolumn{1}{l}{$\begin{array}{l}\text { Workers (Fig. } \\
\text { Woodworkers }\end{array}$} & $\ldots$ & $\ldots$ \\
Building Trades & $\ldots$ & $\ldots$ \\
Drivers, etc. & $\ldots$ & $\ldots$ \\
Clerks (Fig. 4) & $\ldots$ & $\ldots$ \\
Agriculturai Labourers & $\ldots$ \\
Domestic Workers (Fig. & 5) \\
Builders' Labourers & (Fig.
\end{tabular} & $\begin{array}{r}101 \\
49 \\
54 \\
44 \\
80 \\
43 \\
63 \\
32\end{array}$ & \begin{tabular}{|l|l}
$17 \cdot 8$ & \\
$24 \cdot 5$ & \\
$25 \cdot 9$ & \\
$13 \cdot 6$ & \\
$12 \cdot 5$ & 1 \\
$11 \cdot 6$ & \\
$17 \cdot 5$ & \\
$12 \cdot 5$ &
\end{tabular} & $\begin{array}{l}35 \cdot 6 \\
36 \cdot 7 \\
33 \cdot 3 \\
38 \cdot 6 \\
17 \cdot 5 \\
48 \cdot 8 \\
33 \cdot 3 \\
37 \cdot 5\end{array}$ & $\begin{array}{l}32 \cdot 7 \\
26 \cdot 5 \\
29 \cdot 6 \\
22 \cdot 7 \\
33 \cdot 8 \\
23 \cdot 2 \\
41 \cdot 3 \\
43 \cdot 8 \\
31\end{array}$ & $\begin{array}{r}5 \cdot 9 \\
6 \cdot 1 \\
3 \cdot 7 \\
9 \cdot 1 \\
20 \cdot 0 \\
7 \cdot 0 \\
3 \cdot 2 \\
3 \cdot 1 \\
7 \cdot 2\end{array}$ & $\begin{array}{c}1 \cdot 0 \\
4 \cdot 1 \\
3 \cdot 7 \\
6 \cdot 8 \\
10 \cdot 0 \\
1 \cdot 6 \\
\end{array}$ & $\begin{array}{l}6 \cdot 9 \\
2 \cdot 0 \\
3 \cdot 7 \\
9 \cdot 1 \\
6 \cdot 2 \\
9 \cdot 3 \\
3 \cdot 2 \\
3 \cdot 1 \\
10\end{array}$ & $\begin{array}{r}103 \\
142 \\
150 \\
79 \\
72 \\
67 \\
101 \\
72\end{array}$ & \begin{tabular}{|r|r|}
148 \\
152 \\
138 \\
160 \\
73 \\
203 \\
138 \\
156
\end{tabular} & $\begin{array}{r}114 \\
93 \\
104 \\
79 \\
118 \\
81 \\
144 \\
153 \\
111\end{array}$ & $\begin{array}{r}42 \\
44 \\
27 \\
66 \\
144 \\
50 \\
23 \\
22 \\
52\end{array}$ & $\begin{array}{r}17 \\
68 \\
62 \\
113 \\
167 \\
0 \\
27 \\
0\end{array}$ & $\begin{array}{l}68 \\
20 \\
37 \\
90 \\
61 \\
92 \\
32 \\
31\end{array}$ & $\begin{array}{l}5 \\
4 \\
4 \\
4 \\
5 \\
4 \\
4 \\
3\end{array}$ & $\begin{array}{l}99 \\
95 \\
98 \\
50 \\
90 \\
99 \\
99 \\
90\end{array}$ & $\begin{array}{c}\text { N.S. } \\
\text { N.S. } \\
\frac{-10}{\text { N.S. }} \\
\text { N.S. } \\
\mathbf{S . S}\end{array}$ & $\begin{array}{c}99 \\
95 \\
\text { N.S. } \\
\overline{-} \\
99 \\
\text { N.S. } \\
.5\end{array}$ & $\begin{array}{c}\text { N.S. } \\
\text { N.S. } \\
\text { N.S. } \\
\bar{Z} \\
\text { N.S. } \\
\frac{95}{-S}\end{array}$ & $\mid \begin{array}{c}98 \\
\text { N.S. } \\
\frac{98}{-} \\
\text { N.S. } \\
\frac{98}{00}\end{array}$ & $\begin{array}{r}95 \\
90 \\
\mathbf{N} \\
=1 \\
\mathbf{N} \\
9 \\
-1\end{array}$ & $\begin{array}{l}\text { lN.S. } \\
0 \\
\text { s. } \\
\frac{1}{8}= \\
8\end{array}$ \\
\hline
\end{tabular}

Eighteen patients of central type 444 are excluded.

To apply the $\chi^{2}$ test it was often necessary to combine types F1 and Fm, giving four degrees of freedom and, in the case of builders' labourers, types $\mathrm{Lm}$ and $\mathrm{Lf}$ also, leaving three degrees of freedom. 
and in seven of these the level of confidence reaches 95 per cent. or higher. Twelve of the individual comparative ratios for these seven occupational groups are either significantly higher or significantly lower than the expected value of 100 . There is thus strong evidence for concluding that the phenotype characteristics of male mental hospital patients vary systematically with occupation.

Mf.-This phenotype dominance is not significantly characteristic of any single occupational group, but it is common among woodworkers (C.R. 142) and other skilled workers in the building trades (C.R. 150) and, if these two groups are combined, the excess of Mf. types is significant at the 95 per cent. level. Farmers (C.R. 145) also tend to be of this physique and in this they differ from agricultural labourers (C.R. 67).

Ml.-This spare muscular build is outstandingly characteristic of agricultural labourers (C.R. 203), and is also significantly common among woodworkers (C.R. 152) and skilled metal and electrical workers (C.R. 148). Other groups with high ratios are drivers (C.R. 160) and builders' labourers (C.R. 156). In general it can be said that men with Ml. physiques tend to do work which requires a heavy expenditure of physical effort. In contrast the sedentary occupations (finance and public administration, scientists, and clerks) have the lowest ratios.These three groups, in combination, are significantly underrepresented among Ml. types at the 99 per cent. level of confidence.

Lm.-With only two exceptions the comparative ratios for this thin, wiry physique fall between those for sectors Ml. and Lf., adjacent to it on either side. Sector Lm. thus has no clearly defined occupational characteristics of its own. Domestic workers (C.R. 144) are significantly common, and there is also an excess of builders' labourers (C.R. 153), but both of these tendencies are shared with sector Ml.

Lf.-Men with this willowy physique show a highly characteristic pattern of occupational preferences which constitutes virtually a polar opposite to the pattern already discussed for sector Ml. In sector Lf. the sedentary occupations all have high comparative ratios and, in combination, these three groups are significantly more frequent than might have been expected from the distribution of the total sample, at the 99 per cent. level of confidence. With the single exception of farmers, all the remaining non-sedentary occupations have comparative ratios well below expectation. The under-representation of these groups reaches significant levels in the case of unskilled labourers (C.R. 53), skilled metal and electrical workers (C.R. 42), skilled workers in the building trades (C.R. 27), and domestic workers (C.R. 23).

The dichotomy in occupational distribution between sectors Lf. and Ml. is very sharp indeed. The rank order (Tau) correlation between the comparative ratios for the twelve occupational groups in the two sectors is -0.52 . In sector Lf. there are nearly as many men in sedentary as in non-sedentary occupations, but in sector Ml. non-sedentary workers predominate by nearly $10: 1$. This difference is significant far beyond the 99.9 per cent. level of confidence.

Fl.-The samples in the two Fat sectors, Fl. and Fm., total only 88 and 148 , so that for most occupational groups it was necessary to combine the sectors to calculate significance levels. Comparative ratios are given for each sector separately, but they are, of course, subject to greater random variation than those for sectors with larger samples.

To a large extent the occupational distribution of Fl. phenotypes repeats that found in sector Lf. There is again an excess of sedentary workers, significant at the 98 per cent. level of confidence, but scientists (C.R. 47) no longer share in this general trend. Manual workers tend to be under-represented and this is particularly true of semi-skilled and unskilled workers (agricultural labourers, domestic workers, builders' labourers, and unskilled labourers), who make up only 5 per cent. of sector Fl. as against more than 20 per cent. of the total sample. This difference is significant beyond the 99.9 per cent. level.

Fm.-This phenotype dominance does not show a clearly defined occupational configuration. There is a relative shortage of manual workers, as there was in sectors Fl. and Lf., but clerks (C.R. 61) also tend to be scarce. The three highest ratios are found among men engaged in finance and public administration, science and farming, which are the only groups in the present series classified by the Registrar General as belonging to the upper socioeconomic Classes I and II, but the trend is not a significant one.

\section{ILLUSTRATIONS}

To illustrate this phenotype variation among different occupations a number of somatocharts have been prepared (Figs 1 to 6). Each dot represents one man and in this way the exact distributions may more readily be appreciated. 


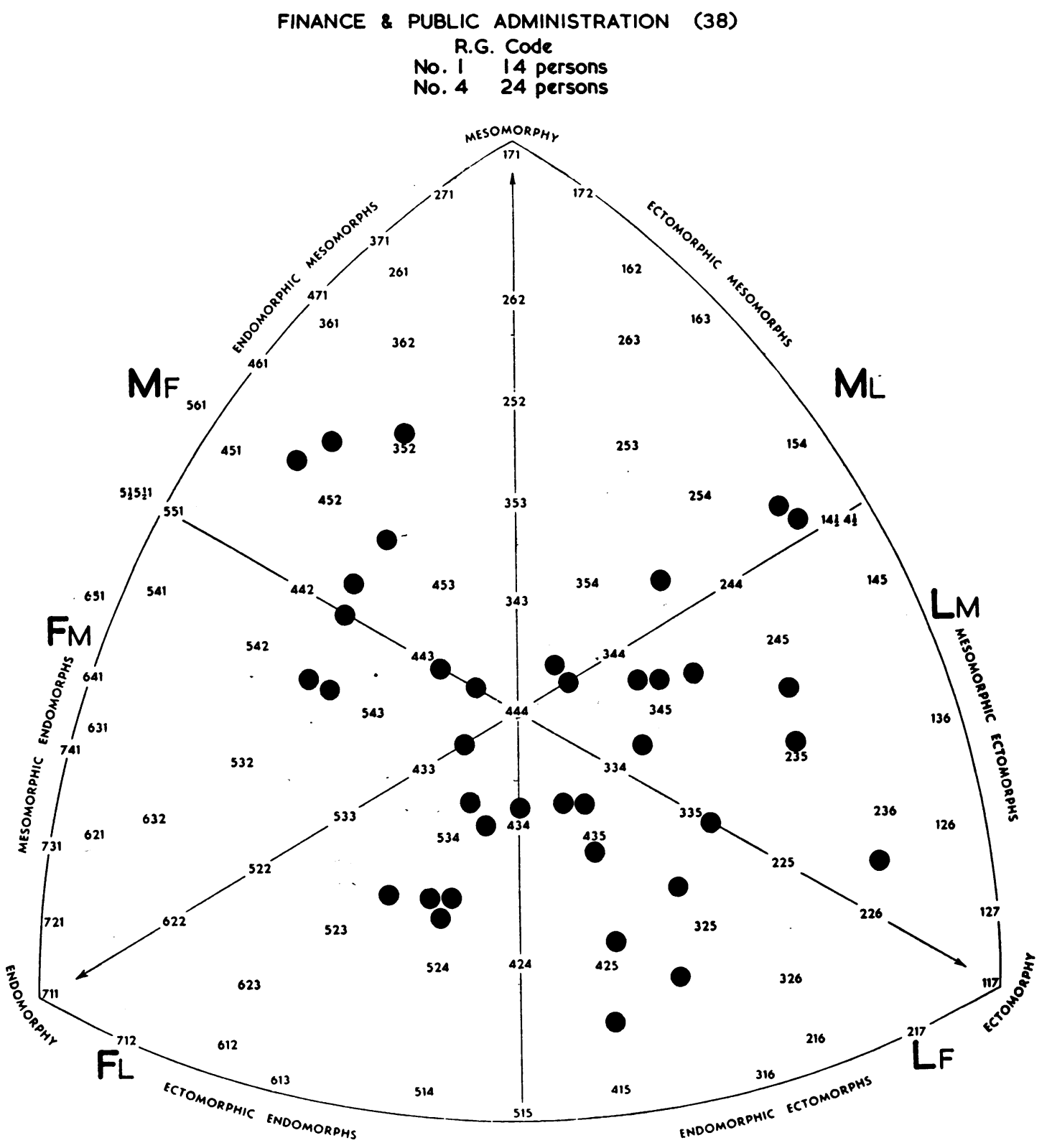

FIGURE 1 


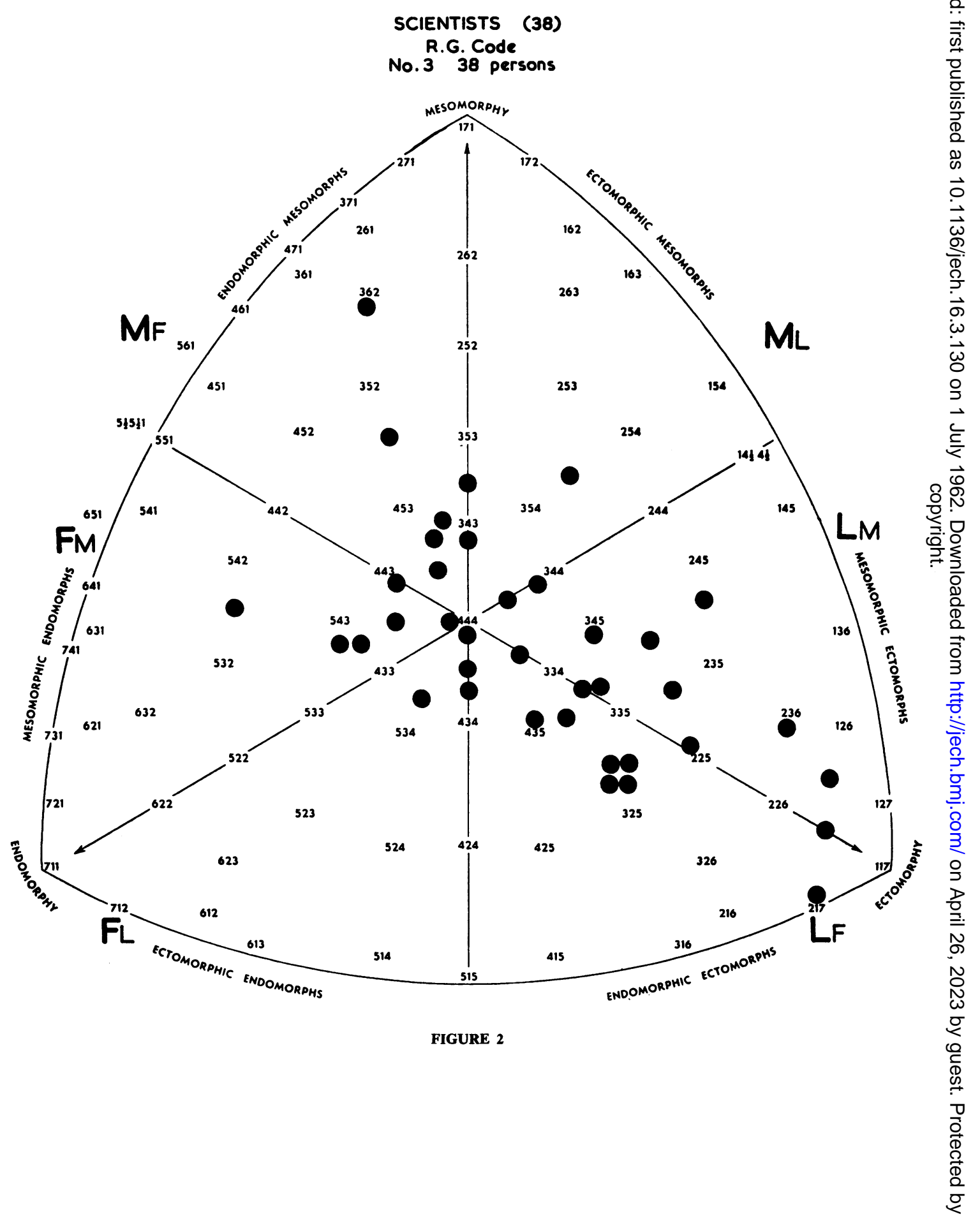




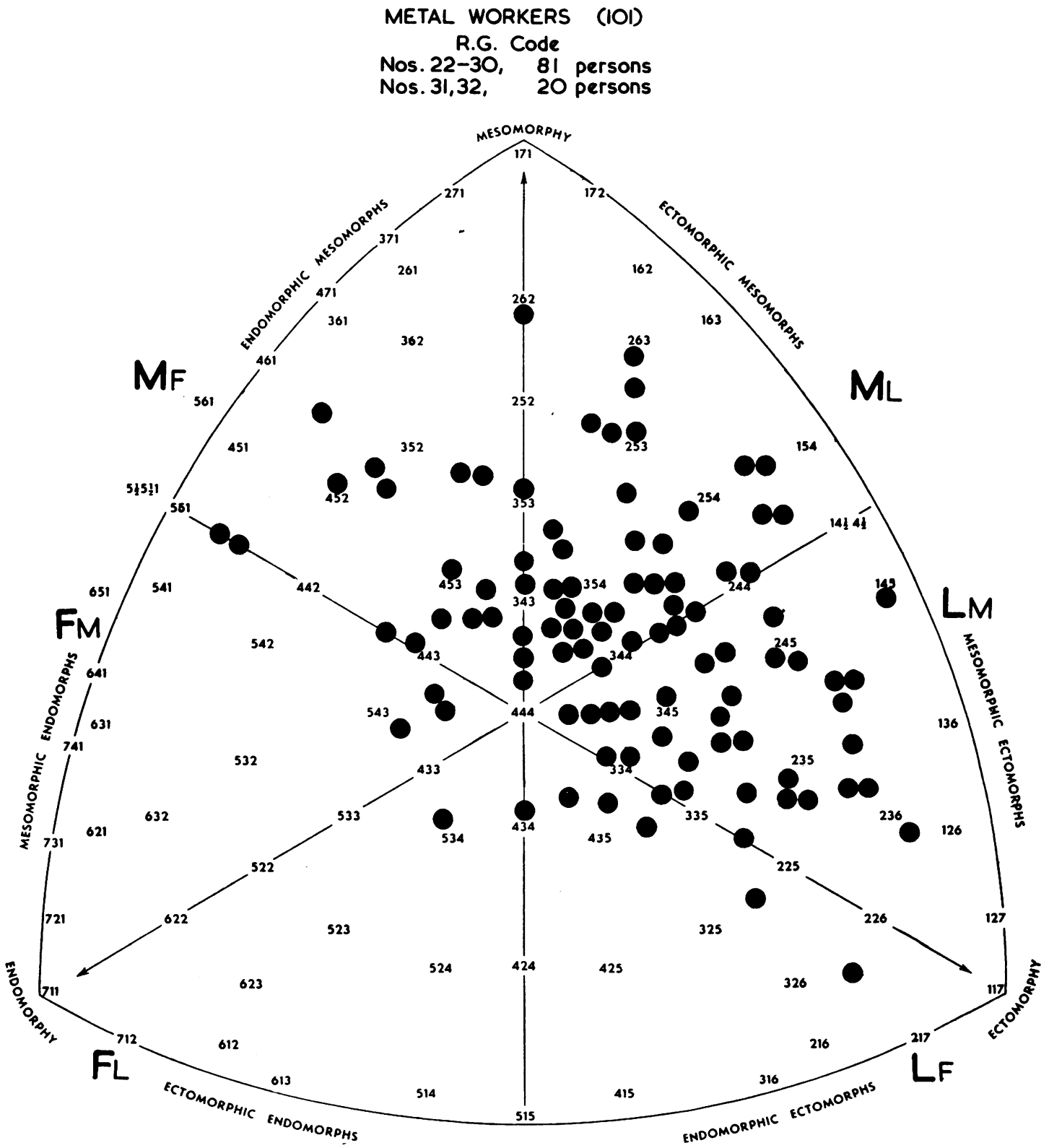

FIGURE 3 


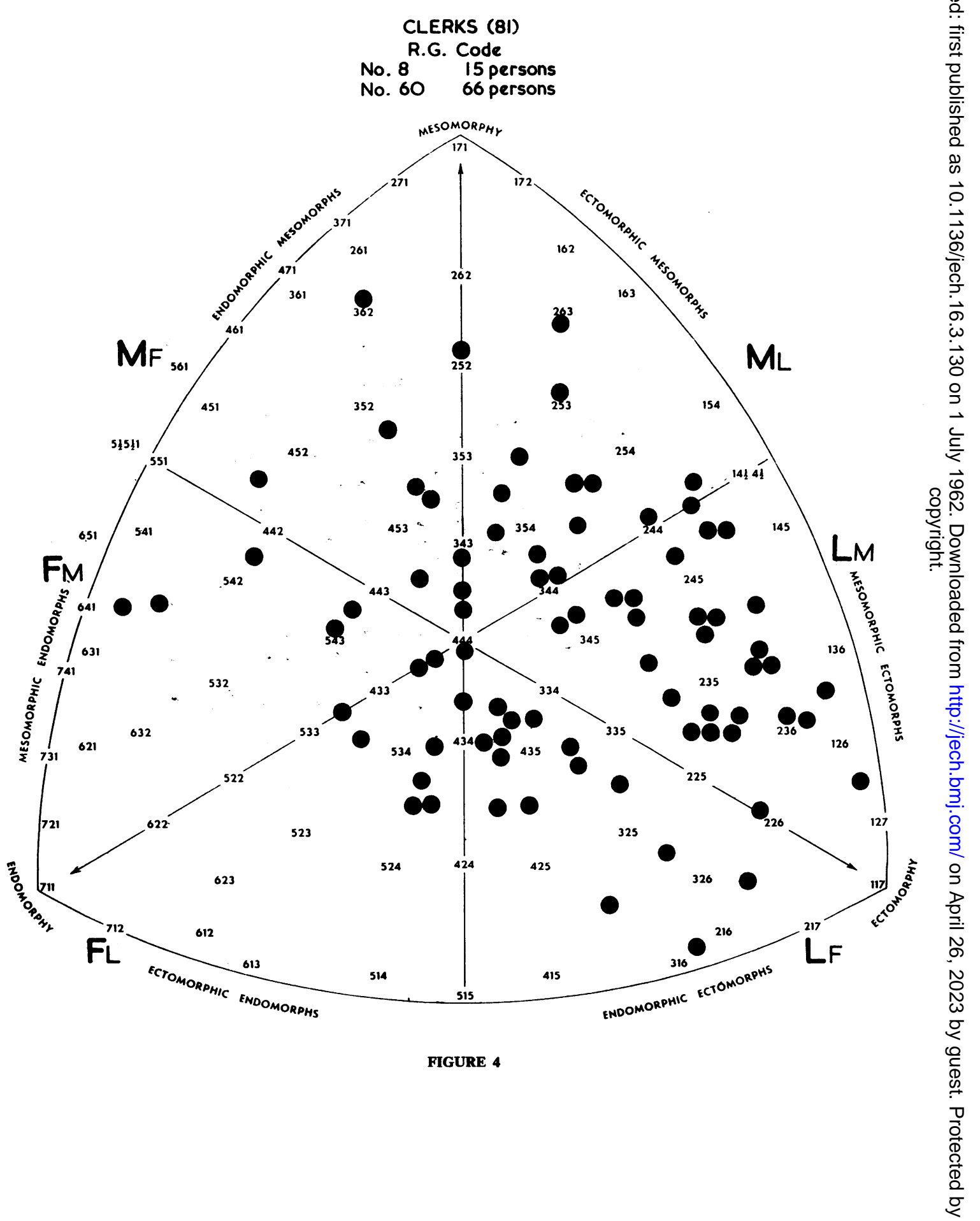




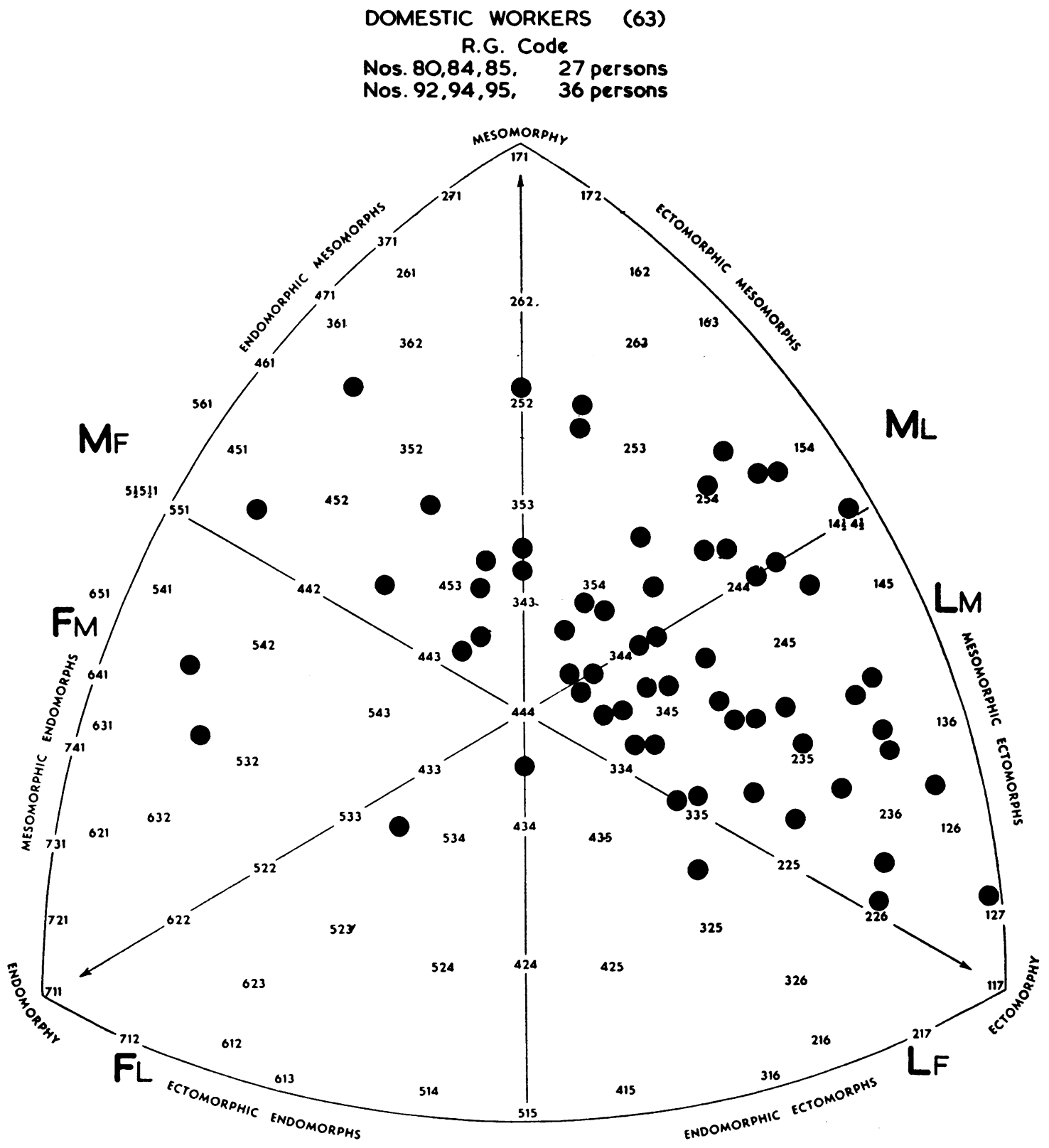

FIGURE 5 


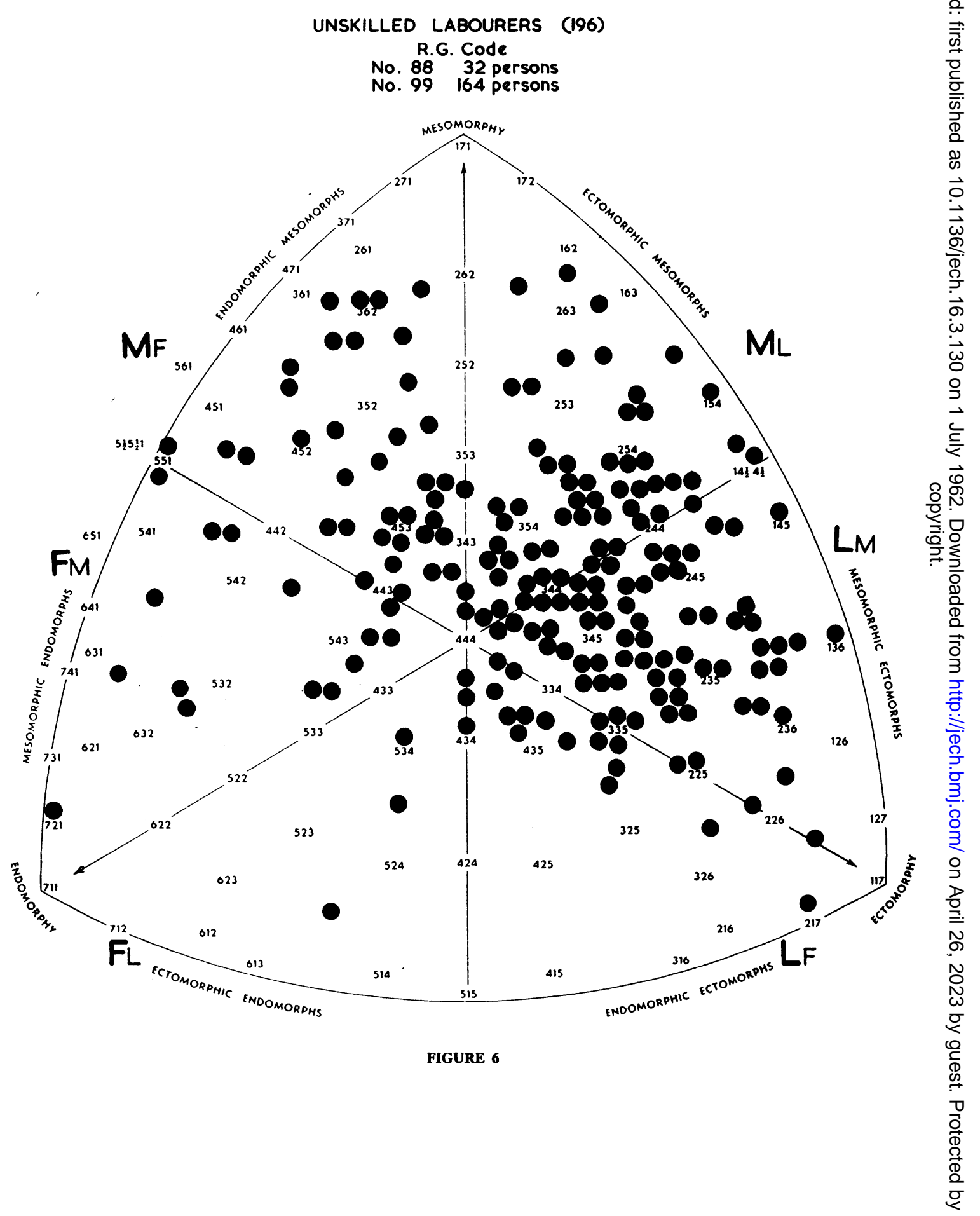


Fig. 7 illustrates the immigrants from European countries. Most were middle-aged men, many Polish, some Hungarian and Yugoslav, and it is interesting to note the marked preponderance of Ml. and Mf. physiques in this immigrant population (see Table II, overleaf).

This bias towards dominant muscularity may be connected with a high proportion of these men having been members of the Free Forces during the second world war, or it may be characteristic of immigrant populations in general. That the latter alternative is more likely is suggested by some similar results from a sample of 3,122 entrants to Birmingham University measured over the past 4 years. In this group, the proportions of foreign students are nearly twice as high in sectors $\mathrm{Ml}$, $\mathrm{Mf}$, and Fm as they are in sectors $\mathrm{Lm}, \mathrm{Lf}$, and $\mathrm{Fl}$.

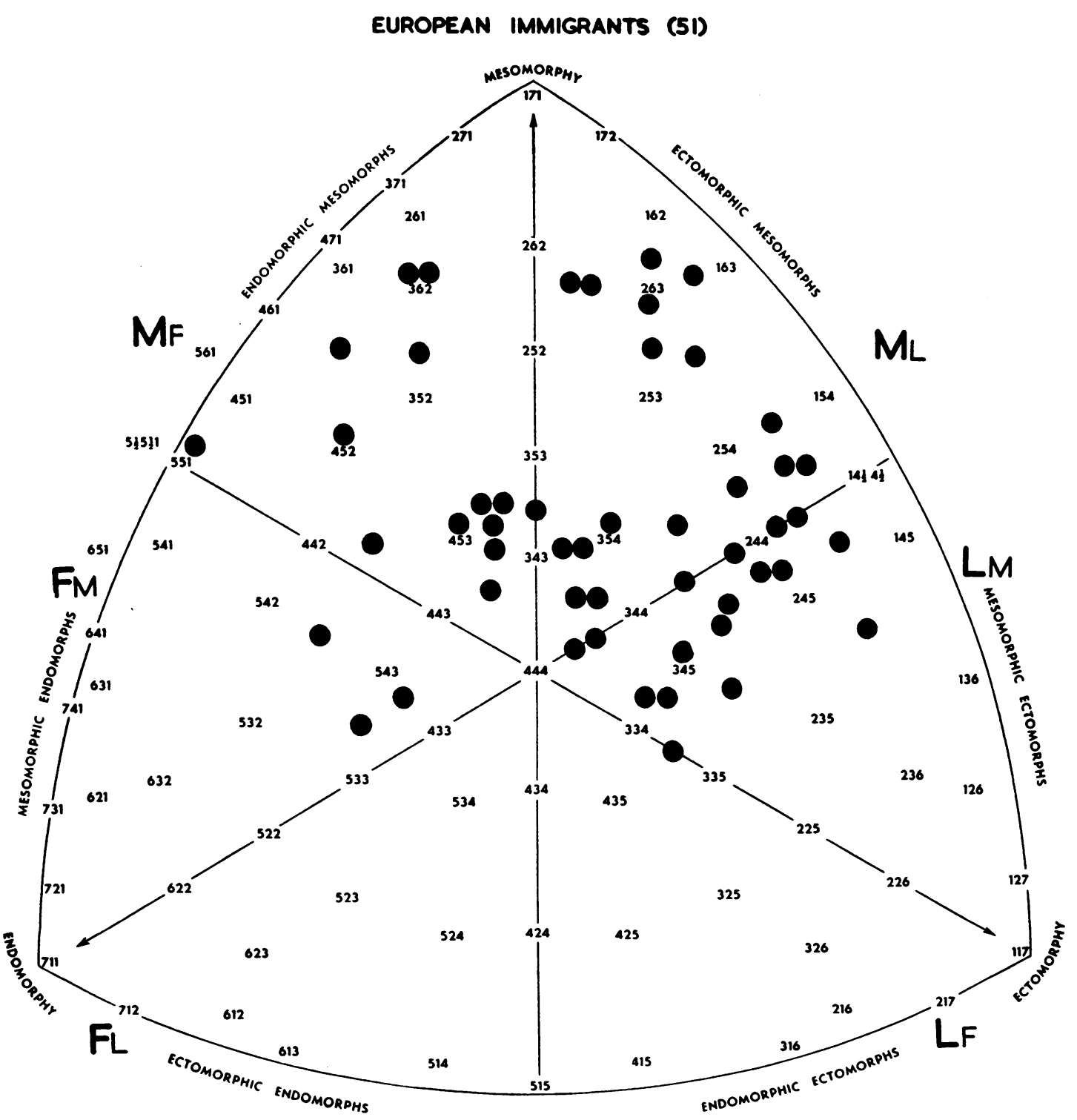


TABLE II

PHENOTYPE DOMINANCE OF EUROPEAN IMMIGRANTS AND OTHER PATIENTS

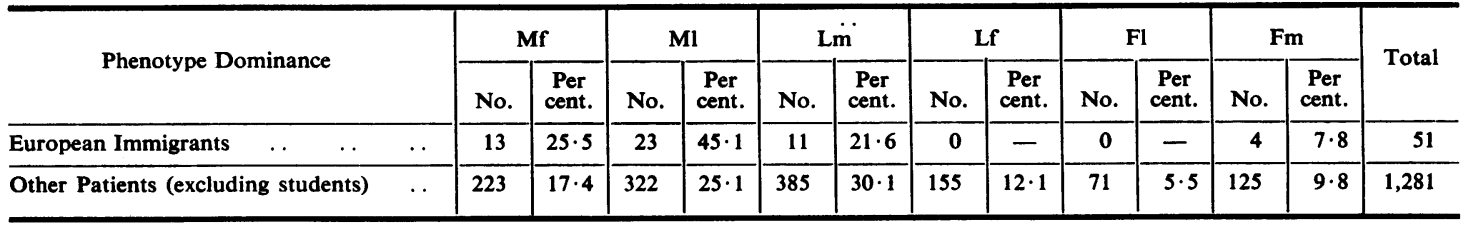

$\chi^{2}{ }_{\triangleleft}=15 \cdot 83$ (with correction: Fl and Fm combined). Sig. 99 per cent.

Fig 8 (opposite), which is of special interest, shows the only group for whom a satisfactory control series of healthy subjects is available, although it has been necessary to include outpatients to get a large enough patient sample. Both patients and controls are drawn from Oxford University students reading English, the controls from men who attended for routine health examinations at a pilot student health service. As may be seen from the illustration and from Table III, there is a marked tendency for the English patients to be rated lower in muscularity than the English controls. Patients outnumber controls by more than three to one in the non-muscular sectors $\mathrm{Lf}$ and $\mathrm{Fl}$, while in the remaining sectors there are more than twice as many controls as patients. To test the significance of these differences it was necessary to combine sectors $\mathrm{Ml}$ and $\mathrm{Lm}$, and also sectors $\mathrm{Lf}$ and $\mathrm{Fl}$, in order to provide expected frequencies of at least five. The overall variation between these four groups is significant at the 99 per cent. level $\left(\chi^{2}{ }_{3}=14 \cdot 86\right.$, with correction).

Table III also contrasts the phenotype distributions of inpatients and healthy controls for students from all faculties. The pattern is very similar: there is a heavy preponderance of patients in sectors $\mathrm{Lf}$ and $\mathrm{Fl}$, and an excess of controls in all the remaining sectors. The overall variation is highly significant $\left(\chi^{2}{ }_{s}=59.54 ; p>99.9\right.$ per cent. $)$. That students of types $\mathrm{Fl}$ and $\mathrm{Lf}$ break down in mental health more often than those of other phenotype dominance has been established for some time (David- son, Lee, Parnell, and Spencer, 1955; Parnell, 1958).

\section{INTERPRETATION}

It will be evident from the foregoing remarks that progress in interpretation of the data so far collected will be handicapped until satisfactory control samples of healthy adults in each occupation have been measured and examined by phenotype dominance. The significant variations so far established may arise through occupational selection or they may be connected with the fact that all were mental hospital patients, in which case it might even be suggested that they represent the misfits at their particular kind of work. Although it seems clear that the particular occupational distributions shown may be biassed, and perhaps heavily so, by the manner in which the sample was selected, the general tendency for men in sedentary and upper social class occupations to be fatter, and for those engaged in hard manual labour to be predominantly muscular will not have escaped notice. It would be reasonable enough to expect such an association, and it has obvious implications for those interested in the aetiology of, for example, coronary disease (Acheson, 1961 ; Heady, Morris, Kagan, and Raffle, 1961).

\section{Mean Measurements}

Table IV (overleaf) gives the mean measurements of each occupational group, together with the means and

TABLE III

PHENOTYPE DOMINANCE OF OXFORD STUDENT PATIENTS AND HEALTHY CONTROLS

\begin{tabular}{|c|c|c|c|c|c|c|c|c|c|c|c|c|c|c|c|c|}
\hline \multicolumn{4}{|c|}{ Phenotype Dominance } & \multicolumn{2}{|c|}{ Mf } & \multicolumn{2}{|c|}{ MI } & \multicolumn{2}{|c|}{$\mathbf{L m}$} & \multicolumn{2}{|c|}{$\mathbf{L f}$} & \multicolumn{2}{|c|}{$\mathbf{F l}$} & \multicolumn{2}{|c|}{ Fm } & Total \\
\hline English Faculty & $\ldots$ & $\begin{array}{l}\text { Patients } \\
\text { Controls }\end{array}$ & $\therefore$ & $\begin{array}{r}3 \\
10\end{array}$ & $\begin{array}{r}7 \cdot 1 \\
23 \cdot 8\end{array}$ & $\begin{array}{l}3 \\
2\end{array}$ & $\begin{array}{l}7 \cdot 1 \\
4 \cdot 8\end{array}$ & $\begin{array}{r}5 \\
13\end{array}$ & $\begin{array}{l}11.9 \\
30.9\end{array}$ & $\begin{array}{r}20 \\
7\end{array}$ & $\begin{array}{l}47 \cdot 6 \\
16 \cdot 7\end{array}$ & $\begin{array}{l}7 \\
1\end{array}$ & $\begin{array}{r}16 \cdot 7 \\
2 \cdot 4\end{array}$ & $\begin{array}{l}4 \\
9\end{array}$ & $\begin{array}{r}9 \cdot 5 \\
21 \cdot 4\end{array}$ & $\begin{array}{l}42 \\
42\end{array}$ \\
\hline All Faculties & $\ldots$ & $\begin{array}{l}\text { Patients } \\
\text { Controls }\end{array}$ & . & $\begin{array}{l}19 \\
87\end{array}$ & $\begin{array}{l}13 \cdot 7 \\
21.7\end{array}$ & $\begin{array}{r}9 \\
63\end{array}$ & $\begin{array}{r}6.5 \\
15.7\end{array}$ & $\begin{array}{r}25 \\
119\end{array}$ & $\begin{array}{l}18 \cdot 0 \\
29 \cdot 7\end{array}$ & $\begin{array}{l}50 \\
50\end{array}$ & $\begin{array}{l}36.0 \\
12.5\end{array}$ & $\begin{array}{l}17 \\
15\end{array}$ & $\begin{array}{r}12.2 \\
3.7\end{array}$ & $\begin{array}{l}19 \\
67\end{array}$ & $\begin{array}{l}13.7 \\
16.7\end{array}$ & $\begin{array}{l}139 \\
401\end{array}$ \\
\hline
\end{tabular}


OXFORD STUDENTS READING ENGLISH (84)

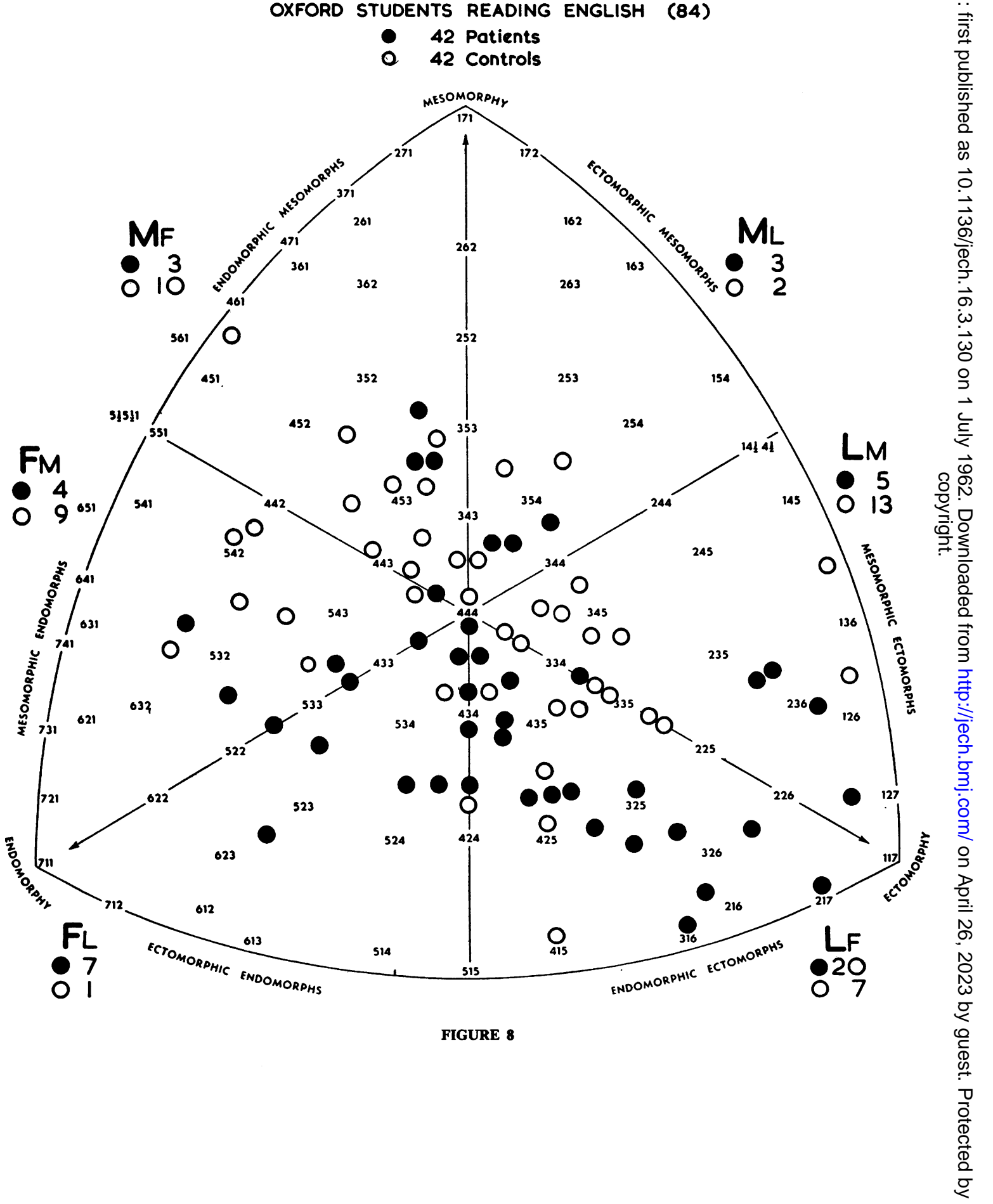


TABLES

MEAN MEASUREMENTS OF MEא

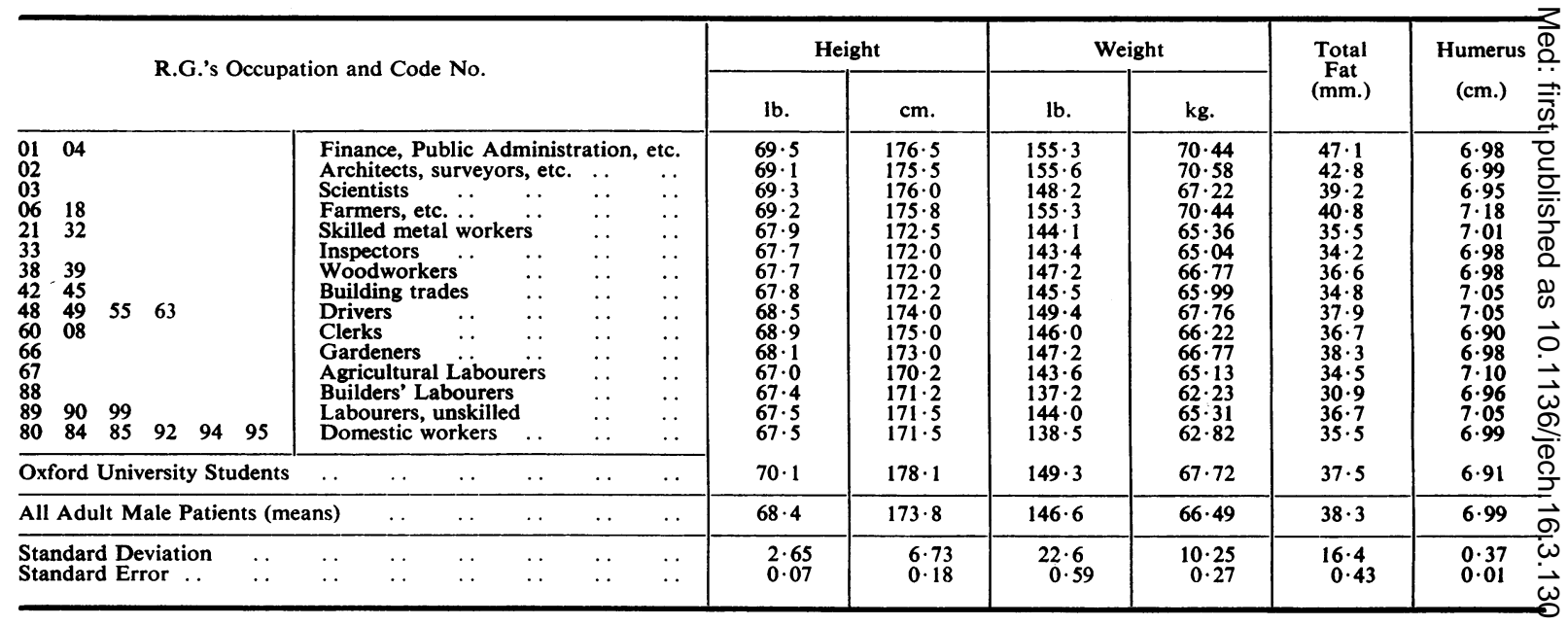

standard deviations for all male patients. The professional classes (Registrar General's Groups I to IV), farmers and Oxford students are outstanding in that they are taller than the rest. In addition, all have fat scores that are higher than the average. Among the remaining occupations clerks are significantly taller than average, and this is associated with the greatest linearity of build recorded for any occupational group. Scientists come close to being as linear in build, and they were the only professional group close to the overall average for weight, for the other professional men were about $8 \mathrm{lb}$. heavier.

\section{Size ANd Body Proportions}

A large variety of two-dimensional scatter diagrams were drawn, employing height on the vertical axis and the remaining measurements in turn along the horizontal axis. In this way the occupational mean values were compared, both for size and body proportions. They are not included here because they add little to the observations already made in the text, and can in any case be plotted by any interested reader from the table provided.

\section{Age, Civil State, and Social Class}

The interpretation of the relationships of phenotype with age and civil state is complicated by the fact that the latter two variables are correlated with each other: young men tend to be single, and older men to be married. Thus any differences in pheno- type distribution found between younger and older men may be due to civil state, or, conversely, differences between single and married men may be due to age. It is therefore necessary when examining the relationship between phenotype and either age or civil state to control the third variable.

Phenotype and Age.-These are significantly associated $\left(\chi^{2}{ }_{5}=45 \cdot 28 ; p>99 \cdot 9\right.$ per cent., see Table V, opposite), and the relationship is a fairly powerful one (contingency coefficient $=0 \cdot 19$ ). There is an excess of type $\mathrm{Lf}$ builds under $\mathbf{4 0}$ years of age, and an excess of muscular builds, mainly of type Mf, after 40 . When civil state is controlled by treating single and married men separately, the patterns are virtually identical with those in the sample as a whole. The $\chi^{2}$ values are lower, but the contingency coefficients $(0.15$ and 0.19 respectively) indicate that this is due to the samples being smaller, rather than to weakening in the strength of the association.

Phenotype and Civil State.-These are also significantly associated $\left(\chi^{2}{ }_{5}=30.04 ; p>99.9\right.$ per cent.) although the relationship is rather less powerful (contingency coefficient $=0 \cdot 16$ ). There are more single men of type Lf and more married men of type Ml. But when the sample is divided into men under $\mathbf{4 0}$ and men over $\mathbf{4 0}$ years of age, significant variation is found only in the under- 40 group. When age is more closely controlled by dividing the sample into 5-year age groups, the association between phenotype and civil state drops below significant 
IV

IN CERTAIN OCCUPATIONS

\begin{tabular}{|c|c|c|c|c|c|c|c|c|c|c|}
\hline \multirow{2}{*}{$\begin{array}{l}\text { Femur } \\
\text { (cm.) }\end{array}$} & \multirow{2}{*}{$\begin{array}{l}\text { Biceps } \\
\text { (cm.) }\end{array}$} & \multirow{2}{*}{$\begin{array}{l}\text { Calf } \\
\text { Girth } \\
\text { (cm.) }\end{array}$} & \multirow{2}{*}{$\underset{\text { (cm.) }}{\text { Bi- }}$} & \multirow{2}{*}{$\begin{array}{c}\text { Bi- } \\
\text { Iliac } \\
\text { (cm.) }\end{array}$} & \multicolumn{2}{|c|}{ Chest } & \multirow{2}{*}{ Fat } & \multirow{2}{*}{ Muscularity } & \multirow{2}{*}{ Linearity } & \multirow{2}{*}{$\begin{array}{c}\text { Numbers } \\
\text { of } \\
\text { Cases }\end{array}$} \\
\hline & & & & & $\begin{array}{l}\text { Width } \\
\text { (cm.) }\end{array}$ & $\begin{array}{c}\text { Depth } \\
\text { (cm.) }\end{array}$ & & & & \\
\hline $\begin{array}{l}9 \cdot 73 \\
9 \cdot 55 \\
9 \cdot 70 \\
9 \cdot 78 \\
9 \cdot 62 \\
9 \cdot 58 \\
9 \cdot 52 \\
9 \cdot 61 \\
9 \cdot 59 \\
9 \cdot 58 \\
9 \cdot 66 \\
9 \cdot 45 \\
9 \cdot 46 \\
9 \cdot 60 \\
9 \cdot 52\end{array}$ & $\begin{array}{l}30 \cdot 8 \\
31 \cdot 9 \\
30.4 \\
31 \cdot 8 \\
30 \cdot 7 \\
30.6 \\
30.7 \\
30.7 \\
31 \cdot 3 \\
30 \cdot 1 \\
30.6 \\
30.7 \\
29.4 \\
30.8 \\
29.7\end{array}$ & $\begin{array}{l}34 \cdot 3 \\
34 \cdot 9 \\
34 \cdot 5 \\
34 \cdot 8 \\
34 \cdot 1 \\
34 \cdot 0 \\
34 \cdot 0 \\
33 \cdot 9 \\
34 \cdot 1 \\
34 \cdot 5 \\
33 \cdot 2 \\
33 \cdot 1 \\
33 \cdot 0 \\
34 \cdot 0 \\
33 \cdot 4\end{array}$ & $\begin{array}{l}38 \cdot 1 \\
38 \cdot 0 \\
39 \cdot 0 \\
38 \cdot 1 \\
38 \cdot 1 \\
38 \cdot 4 \\
38 \cdot 1 \\
38 \cdot 3 \\
38 \cdot 7 \\
38 \cdot 1 \\
37 \cdot 5 \\
37 \cdot 4 \\
38 \cdot 1 \\
37 \cdot 7 \\
37 \cdot 3\end{array}$ & $\begin{array}{l}28 \cdot 9 \\
28 \cdot 6 \\
28 \cdot 2 \\
28 \cdot 7 \\
28 \cdot 4 \\
28 \cdot 6 \\
28 \cdot 6 \\
28 \cdot 5 \\
28 \cdot 6 \\
28 \cdot 6 \\
28 \cdot 2 \\
28 \cdot 3 \\
28 \cdot 5 \\
28 \cdot 4 \\
28 \cdot 6\end{array}$ & $\begin{array}{l}27 \cdot 8 \\
27 \cdot 9 \\
27 \cdot 7 \\
28 \cdot 1 \\
27 \cdot 2 \\
27 \cdot 3 \\
27 \cdot 4 \\
27 \cdot 6 \\
27 \cdot 5 \\
27 \cdot 5 \\
27 \cdot 5 \\
26 \cdot 9 \\
26 \cdot 8 \\
27 \cdot 2 \\
26 \cdot 6\end{array}$ & $\begin{array}{l}21 \cdot 2 \\
21 \cdot 4 \\
20 \cdot 5 \\
20 \cdot 9 \\
20 \cdot 5 \\
20 \cdot 5 \\
20 \cdot 5 \\
21 \cdot 2 \\
20 \cdot 8 \\
20 \cdot 6 \\
21 \cdot 2 \\
20 \cdot 9 \\
20 \cdot 5 \\
20 \cdot 9 \\
20 \cdot 7\end{array}$ & $\begin{array}{l}3 \cdot 75 \\
3 \cdot 86 \\
3 \cdot 54 \\
3 \cdot 50 \\
3 \cdot 11 \\
3 \cdot 19 \\
3 \cdot 09 \\
3 \cdot 19 \\
3 \cdot 24 \\
3 \cdot 32 \\
3 \cdot 14 \\
3 \cdot 02 \\
2 \cdot 91 \\
3 \cdot 22 \\
2 \cdot 99\end{array}$ & $\begin{array}{l}3 \cdot 71 \\
3 \cdot 86 \\
3 \cdot 75 \\
4 \cdot 21 \\
4 \cdot 35 \\
4 \cdot 29 \\
4 \cdot 36 \\
4 \cdot 45 \\
4 \cdot 35 \\
3 \cdot 87 \\
4 \cdot 06 \\
4 \cdot 38 \\
4 \cdot 22 \\
4 \cdot 38 \\
4 \cdot 23\end{array}$ & $\begin{array}{l}4 \cdot 25 \\
4 \cdot 00 \\
4 \cdot 44 \\
4 \cdot 10 \\
4 \cdot 18 \\
4 \cdot 05 \\
4 \cdot 20 \\
4 \cdot 04 \\
4 \cdot 02 \\
4 \cdot 48 \\
4 \cdot 21 \\
3 \cdot 99 \\
4 \cdot 33 \\
4 \cdot 05 \\
4 \cdot 33\end{array}$ & $\begin{array}{r}38 \\
18 \\
38 \\
40 \\
101 \\
25 \\
50 \\
55 \\
45 \\
81 \\
27 \\
43 \\
32 \\
164 \\
63\end{array}$ \\
\hline $9 \cdot 68$ & $30 \cdot 4$ & $35 \cdot 6$ & $39 \cdot 0$ & $27 \cdot 8$ & $27 \cdot 5$ & $19 \cdot 7$ & $3 \cdot 93$ & $3 \cdot 54$ & $4 \cdot 32$ & 143 \\
\hline $9 \cdot 62$ & $30 \cdot 6$ & $34 \cdot 3$ & $38 \cdot 2$ & $28 \cdot 4$ & $27 \cdot 4$ & $20 \cdot 6$ & $3 \cdot 39$ & $4 \cdot 07$ & $4 \cdot 20$ & 1,488 \\
\hline $\begin{array}{l}0.46 \\
0.01\end{array}$ & $\begin{array}{l}2 \cdot 82 \\
0 \cdot 07\end{array}$ & $\begin{array}{l}2.74 \\
0.07\end{array}$ & $\begin{array}{l}1.98 \\
0.05\end{array}$ & $\begin{array}{l}1.70 \\
0.05\end{array}$ & $\begin{array}{l}1.96 \\
0.05\end{array}$ & $\begin{array}{l}2.12 \\
0.06\end{array}$ & $\begin{array}{l}1.03 \\
0.03\end{array}$ & $\begin{array}{l}0.96 \\
0.03\end{array}$ & $\begin{array}{l}1 \cdot 19 \\
0.03\end{array}$ & $\begin{array}{l}1,488 \\
1,488\end{array}$ \\
\hline
\end{tabular}

TABLE V

DISTRIBUTION OF PHENOTYPE DOMINANCE BY AGE AND CIVIL STATE

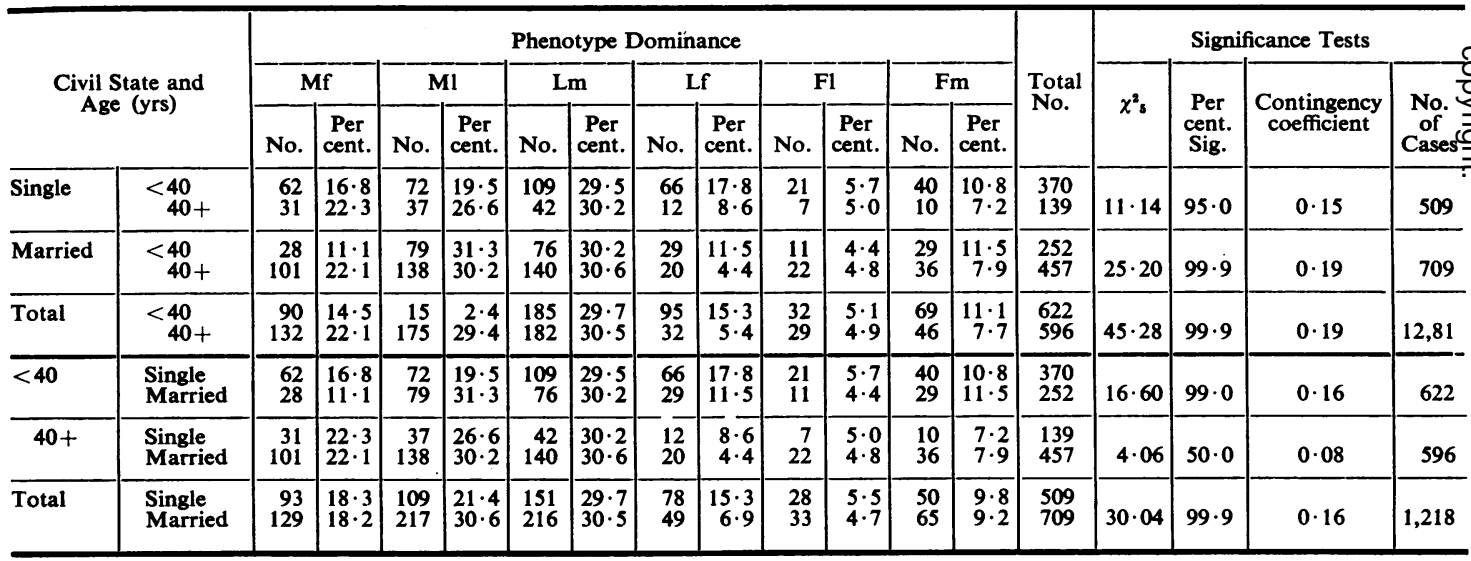

Men aged under 20 and students are excluded, and eighteen patients of central type 444 are omitted.

levels except in the case of men aged 35-39. In this group there is an excess of single men of type Mf and an excess of married men of type Ml. The confidence level is just short of 95 per cent. $\left(\chi^{2}{ }_{3}=7 \cdot 77\right)$, and the contingency coefficient $(0 \cdot 20)$ is larger than that for the sample as a whole. These differences may, of course, be due to chance, but it is worth noting that the tendency for more Ml men to be married is found in every group up to age 55 . This suggests that although the relationship between civil state and phenotype is largely due to age, there is a genuine tendency, at each age level, for men of Ml physique to be married more often than men of other physiques.

Phenotype and Social Class.-With the above findings in mind it is desirable to control both age and civil state when examining the association between phenotype and social class. For the sample as a whole, the association is a very strong one $\left(\chi^{2}{ }_{10}=50.57 ; p>99.9\right.$ per cent., see Table VI, overleaf).

The main sources of significant variation are as follows:

(a) The muscular physical type $\mathrm{Ml}$ is outstandingly 
characteristic of semi-skilled and unskilled workers from Social Classes IV and V. Conversely in Social Classes I and II, made up chiefly of professional workers and businessmen, there are relatively few men of this phenotype.

(b) In the non-muscular sectors $\mathrm{Fl}$ and $\mathrm{Lf}$ the social class configuration typical of sector $\mathrm{Ml}$ is reversed. There are proportionally twice as many men of these phenotypes in Classes I and II as there are in Classes IV and V.

The general trend of these results for the total sample is, of course, in keeping with the observations already made when examining the phenotype distribution of individual occupations. When the sample is controlled by age and civil state, however, it is found that the strength of the association between phenotype and social class varies considerably between the various subgroups. For married men over the age of 40 , the association is significant and powerful $\left(\chi^{2}{ }_{10}=48 \cdot 8 ; p>99.9\right.$ per cent. ; contingency coefficient $=0 \cdot 31$ ). Married men under 40 show the same trends, but the relationship is less powerful and does not quite reach a significant level $\left(\chi_{8}^{2}=14 \cdot 8\right.$; $p>90<95$ per cent.; contingency coefficient $=0 \cdot 24$ ).

There is no evidence of a significant relationship among single men under 40 , while there are too few single men over 40 to carry out a satisfactory test.

Why the relationship between social class and phenotype should vary so much with age and civil state is not entirely clear. A possible reason might be that men who break down early in life are prevented, by their mental illness, from reaching the occupational status they otherwise might have achieved. Men with Lf physiques, as has been shown, tend to have high occupational status; they are relatively most common in Classes I and II. Despite this, they also tend to break down early. It might, therefore, be expected that an appreciable number of young Lf men might be ascribed an occupational status below the potential they might have achieved had they remained healthy until later in life. Inspection of the frequencies in Table VI suggests that this may indeed be so. One of the major reasons why the association between phenotype and social class is not significant among single men under 40 is the relatively large number of $\mathrm{Lf}$ physiques in Classes IV and V.

The overall picture, however, is undoubtedly complicated, and it is more than probable that other factors are involved. Social class, phenotype, age, and civil state are all associated significantly with diagnosis and it seems likely that some of the relationships already discussed would vary significantly between the different diagnostic categories, but when an attempt was made to control for diagnosis, many of the subsamples became unsatisfactorily small. The sample would need to be extended to perhaps five times its present size before the complex interactions between social class, phenotype, diagnosis, age, and civil state could be interpreted meaningfully.

TABLE VI

DISTRIBUTION OF PHENOTYPE DOMINANCE BY SOCIAL CLASS, AGE, AND CIVIL STATE

\begin{tabular}{|c|c|c|c|c|c|c|c|c|c|c|c|c|c|c|c|c|}
\hline \multirow{3}{*}{\multicolumn{2}{|c|}{ Social Class }} & \multirow{3}{*}{$\begin{array}{c}\text { Age } \\
\text { (yrs) }\end{array}$} & \multirow{3}{*}{$\begin{array}{l}\text { Civil } \\
\text { State* }\end{array}$} & \multicolumn{12}{|c|}{ Phenotype Dominance } & \multirow{3}{*}{$\begin{array}{c}\text { Total } \\
\text { No. }\end{array}$} \\
\hline & & & & \multicolumn{2}{|c|}{ Mf } & \multicolumn{2}{|c|}{ M1 } & \multicolumn{2}{|c|}{ Lm } & \multicolumn{2}{|c|}{ Lf } & \multicolumn{2}{|c|}{$\mathbf{F l}$} & \multicolumn{2}{|c|}{$\mathbf{F m}$} & \\
\hline & & & & No. & $\begin{array}{c}\text { Per } \\
\text { cent. }\end{array}$ & No. & $\begin{array}{c}\text { Per } \\
\text { cent. }\end{array}$ & No. & $\begin{array}{c}\text { Per } \\
\text { cent. }\end{array}$ & No. & $\begin{array}{c}\text { Per } \\
\text { cent. }\end{array}$ & No. & $\begin{array}{c}\text { Per } \\
\text { cent. }\end{array}$ & No. & $\begin{array}{c}\text { Per } \\
\text { cent. }\end{array}$ & \\
\hline \multirow[t]{2}{*}{$I$ and $11 .}$. & \multirow[t]{2}{*}{. } & $\begin{array}{l}<40 \\
<40 \\
40+ \\
40+\end{array}$ & $\begin{array}{l}\mathbf{S} \\
\mathbf{M} \\
\mathbf{S} \\
\mathbf{M}\end{array}$ & $\begin{array}{r}10 \\
10 \\
5 \\
25\end{array}$ & $\begin{array}{l}18 \cdot 2 \\
16 \cdot 1 \\
18 \cdot 5 \\
20 \cdot 3\end{array}$ & $\begin{array}{r}5 \\
13 \\
4 \\
23\end{array}$ & $\begin{array}{r}9 \cdot 1 \\
21 \cdot 0 \\
14 \cdot 8 \\
18 \cdot 7\end{array}$ & $\begin{array}{r}13 \\
14 \\
9 \\
33\end{array}$ & $\begin{array}{l}23 \cdot 6 \\
22 \cdot 6 \\
33 \cdot 3 \\
26 \cdot 8\end{array}$ & $\begin{array}{r}16 \\
10 \\
3 \\
13\end{array}$ & $\begin{array}{l}29 \cdot 1 \\
16 \cdot 1 \\
11 \cdot 1 \\
10 \cdot 6\end{array}$ & $\begin{array}{r}2 \\
5 \\
4 \\
15\end{array}$ & $\begin{array}{r}3 \cdot 6 \\
8 \cdot 1 \\
14 \cdot 8 \\
12 \cdot 2\end{array}$ & $\begin{array}{r}9 \\
10 \\
2 \\
14\end{array}$ & $\begin{array}{r}16 \cdot 4 \\
16 \cdot 1 \\
7 \cdot 4 \\
11 \cdot 4\end{array}$ & $\begin{array}{r}55 \\
62 \\
27 \\
123\end{array}$ \\
\hline & & Total & . & 50 & $18 \cdot 7$ & 45 & $16 \cdot 9$ & 69 & $25 \cdot 8$ & 42 & $15 \cdot 7$ & 26 & $9 \cdot 7$ & 35 & $13 \cdot 1$ & 267 \\
\hline & \multirow[t]{2}{*}{. } & $\begin{array}{l}<40 \\
<40 \\
40+ \\
40+\end{array}$ & $\begin{array}{l}\mathbf{S} \\
\mathbf{M} \\
\mathbf{S} \\
\mathbf{M} \\
\end{array}$ & $\begin{array}{l}25 \\
14 \\
15 \\
42 \\
\end{array}$ & $\begin{array}{l}17 \cdot 1 \\
10 \cdot 5 \\
33 \cdot 3 \\
22 \cdot 3 \\
\end{array}$ & $\begin{array}{r}29 \\
42 \\
9 \\
61 \\
\end{array}$ & $\begin{array}{l}19 \cdot 9 \\
31 \cdot 6 \\
20 \cdot 0 \\
32 \cdot 4 \\
\end{array}$ & $\begin{array}{l}41 \\
42 \\
11 \\
62 \\
\end{array}$ & $\begin{array}{l}28 \cdot 1 \\
31 \cdot 6 \\
24 \cdot 4 \\
33 \cdot 0 \\
\end{array}$ & $\begin{array}{r}27 \\
15 \\
3 \\
6 \\
\end{array}$ & $\begin{array}{r}18 \cdot 5 \\
11 \cdot 3 \\
6 \cdot 7 \\
3 \cdot 2 \\
\end{array}$ & $\begin{array}{r}12 \\
6 \\
2 \\
5 \\
\end{array}$ & $\begin{array}{l}8 \cdot 2 \\
4 \cdot 5 \\
4 \cdot 4 \\
2 \cdot 7 \\
\end{array}$ & $\begin{array}{r}12 \\
14 \\
5 \\
12 \\
\end{array}$ & $\begin{array}{r}8 \cdot 2 \\
10 \cdot 5 \\
11 \cdot 1 \\
6.4 \\
\end{array}$ & $\begin{array}{r}146 \\
133 \\
45 \\
188 \\
\end{array}$ \\
\hline & & Total & $\ldots$ & 96 & $18 \cdot 7$ & 141 & $27 \cdot 5$ & 156 & $30 \cdot 5$ & 51 & $10 \cdot 0$ & 25 & $4 \cdot 9$ & 43 & $8 \cdot 4$ & 512 \\
\hline \multirow[t]{2}{*}{ IV and V } & \multirow[t]{2}{*}{. } & $\begin{array}{l}<40 \\
<40 \\
40+ \\
40+\end{array}$ & $\begin{array}{l}\mathbf{S} \\
\mathbf{M} \\
\mathbf{S} \\
\mathbf{M} \\
\end{array}$ & $\begin{array}{r}27 \\
4 \\
11 \\
34 \\
\end{array}$ & $\begin{array}{r}16.0 \\
7.0 \\
16.4 \\
23.3 \\
\end{array}$ & $\begin{array}{l}38 \\
24 \\
24 \\
54\end{array}$ & $\begin{array}{l}22 \cdot 5 \\
42 \cdot 1 \\
35 \cdot 8 \\
37 \cdot 0 \\
\end{array}$ & $\begin{array}{l}55 \\
20 \\
22 \\
45\end{array}$ & $\begin{array}{l}32 \cdot 5 \\
35 \cdot 1 \\
32 \cdot 8 \\
30 \cdot 8 \\
\end{array}$ & $\begin{array}{r}23 \\
4 \\
6 \\
1\end{array}$ & $\begin{array}{r}13.6 \\
7.0 \\
9.0 \\
0.7 \\
\end{array}$ & $\begin{array}{l}7 \\
0 \\
1 \\
2 \\
\end{array}$ & $\begin{array}{l}4 \cdot 1 \\
1 \cdot 5 \\
1 \cdot 4\end{array}$ & $\begin{array}{r}19 \\
5 \\
3 \\
10 \\
\end{array}$ & $\begin{array}{r}11.2 \\
8.8 \\
4.5 \\
6.8 \\
\end{array}$ & $\begin{array}{r}169 \\
57 \\
67 \\
146\end{array}$ \\
\hline & & Total & . & 76 & $17 \cdot 3$ & 140 & 31.9 & 142 & $32 \cdot 3$ & 34 & $7 \cdot 7$ & 10 & $2 \cdot 3$ & 37 & $8 \cdot 4$ & 439 \\
\hline
\end{tabular}

* $\mathbf{S}=$ single. $\quad \mathbf{M}=$ married, widowed and divorced.

Men under 20 years and students are excluded, and eighteen patients of central type 444 are omitted. 
Phenotype Dominance and Diagnosis

Although the higher-order interactions between the variables measured in this study must remain obscure, the relationships between phenotype dominance and diagnosis are quite straightforward if social class is ignored. The distributions are given in Table VII. For the total sample, the variations in phenotype distribution between the three diagnostic categories are significant $\left(\chi^{2}{ }_{10}=46 \cdot 1 ; p>99.9\right.$ per cent.) and fairly powerful (contingency coefficient $=0 \cdot 19$ ). Unfortunately the sample contains so few schizophrenics either married or over 40 years of age that control by civil state and age is not feasible, but among single men under 40 the relationship is essentially the same as it is in the sample as a whole $\left(\chi_{8}^{2}=19 \cdot 7 ; p>98<99\right.$ per cent.; contingency coefficient $=0 \cdot 21$ ).

The main contribution to significant variation comes from sector Lf where there are nearly twice as many schizophrenics and only 60 per cent. as many depressives as might be expected from the distribution of the sample as a whole. Schizophrenics are also common in sector Fl, but are relatively lacking in the muscular sectors Mf and Ml. These findings are not new, and have been commented on in greater detail elsewhere (Parnell, 1958). Depression was commoner than expected in types $\mathrm{Mf}$ and Fm. The remaining diagnoses, consisting of disorders of character, behaviour and intelligence were commonest in type Ml, but the tendency for them to localise in this area of the somatochart cannot be said to be strong.

\section{SUMMARY}

1,488 men admitted to four mental hospitals in the southern part of the Oxford region had the following measurements taken: height,- weight, skinfold thickness, bicondylar widths of humerus and femur, biceps and calf girths. Patients were allotted a three-numeral phenotype index indicating their relative degrees of fatness, muscularity, and linearity of build.

Occupations were classified by the Registrar General's code, and twelve groups were found with samples exceeding thirty in number. Of these, ten showed greater variation in their phenotype distribution than might have been expected by chance and in seven the level of confidence reached at least 95 per cent. These significant variations may arise through occupational selection, which seems both reasonable and likely, or they may be connected in some way not readily understood with the fact that all were mental hospital patients. There is a general tendency for men in sedentary and upper social class occupations to be fatter, and for those doing hard manual work to be more muscular.

The variation of phenotype dominance with age is significant, so too that with civil state, but the former is more powerful and probably accounts at least in part for the latter. With age and civil state controlled,

TABLE VII

DISTRIBUTION OF PHENOTYPE DOMINANCE BY DIAGNOSIS, AGE, AND CIVIL STATE

\begin{tabular}{|c|c|c|c|c|c|c|c|c|c|c|c|c|c|c|c|c|}
\hline \multirow{3}{*}{ Diagnosis } & & \multirow{3}{*}{$\begin{array}{l}\text { Age } \\
\text { (yrs) }\end{array}$} & \multirow{3}{*}{$\begin{array}{c}\text { Civil } \\
\text { State* }\end{array}$} & \multicolumn{12}{|c|}{ Phenotype Dominance } & \multirow{3}{*}{$\begin{array}{c}\text { Total } \\
\text { No. }\end{array}$} \\
\hline & & & & \multicolumn{2}{|c|}{ Mf } & \multicolumn{2}{|c|}{ Ml } & \multicolumn{2}{|c|}{$\mathbf{L m}$} & \multicolumn{2}{|c|}{ Lf } & \multicolumn{2}{|c|}{$\mathbf{F l}$} & \multicolumn{2}{|c|}{$\mathbf{F m}$} & \\
\hline & & & & No. & $\begin{array}{c}\text { Per } \\
\text { cent. }\end{array}$ & No. & $\begin{array}{c}\text { Per } \\
\text { cent. }\end{array}$ & No. & $\begin{array}{c}\text { Per } \\
\text { cent. }\end{array}$ & No. & $\begin{array}{c}\text { Per } \\
\text { cent. }\end{array}$ & No. & $\begin{array}{c}\text { Per } \\
\text { cent. }\end{array}$ & No. & $\begin{array}{c}\text { Per } \\
\text { cent. }\end{array}$ & \\
\hline \multirow[t]{2}{*}{ Depression } & \multirow[t]{2}{*}{$\cdots$} & $\begin{array}{l}<40 \\
<40 \\
40+ \\
40+\end{array}$ & $\begin{array}{l}\mathbf{S} \\
\mathbf{M} \\
\mathbf{S} \\
\mathbf{M}\end{array}$ & $\begin{array}{l}18 \\
11 \\
16 \\
62\end{array}$ & $\begin{array}{l}25 \cdot 0 \\
10 \cdot 4 \\
26 \cdot 7 \\
22 \cdot 5\end{array}$ & $\begin{array}{l}13 \\
38 \\
13 \\
81\end{array}$ & $\begin{array}{l}18 \cdot 1 \\
35 \cdot 8 \\
21 \cdot 7 \\
29 \cdot 5\end{array}$ & $\begin{array}{l}19 \\
28 \\
16 \\
84\end{array}$ & $\begin{array}{l}26 \cdot 4 \\
26.4 \\
26 \cdot 7 \\
30 \cdot 5\end{array}$ & $\begin{array}{r}7 \\
11 \\
5 \\
14\end{array}$ & $\begin{array}{r}9 \cdot 7 \\
10 \cdot 4 \\
8 \cdot 3 \\
5 \cdot 1\end{array}$ & $\begin{array}{r}3 \\
7 \\
2 \\
11\end{array}$ & $\begin{array}{l}4 \cdot 2 \\
6 \cdot 6 \\
3 \cdot 3 \\
4 \cdot 0\end{array}$ & $\begin{array}{r}12 \\
11 \\
8 \\
23\end{array}$ & $\begin{array}{r}16.7 \\
10.4 \\
13.3 \\
8.4\end{array}$ & $\begin{array}{r}72 \\
106 \\
60 \\
275\end{array}$ \\
\hline & & Total & $\ldots$ & 107 & $20 \cdot 9$ & 145 & $28 \cdot 3$ & 147 & $28 \cdot 7$ & 37 & $7 \cdot 2$ & 23 & $4 \cdot 5$ & 54 & $10 \cdot 5$ & 513 \\
\hline \multirow[t]{2}{*}{ Schizophrenia } & \multirow[t]{2}{*}{$\cdots$} & $\begin{array}{l}<40 \\
<40 \\
40+ \\
40+\end{array}$ & $\begin{array}{l}\mathbf{S} \\
\mathbf{M} \\
\mathbf{S} \\
\mathbf{M}\end{array}$ & $\begin{array}{r}18 \\
3 \\
2 \\
2\end{array}$ & $\begin{array}{l}13 \cdot 2 \\
14 \cdot 3 \\
22 \cdot 2 \\
40 \cdot 0\end{array}$ & $\begin{array}{r}18 \\
3 \\
2 \\
1\end{array}$ & $\begin{array}{l}13 \cdot 2 \\
14 \cdot 3 \\
22 \cdot 2 \\
20 \cdot 0\end{array}$ & $\begin{array}{r}40 \\
11 \\
3 \\
2\end{array}$ & $\begin{array}{l}29.4 \\
52.4 \\
33.3 \\
40.0\end{array}$ & $\begin{array}{r}35 \\
1 \\
2 \\
0\end{array}$ & $\begin{array}{r}25 \cdot 7 \\
4 \cdot 8 \\
22 \cdot 2 \\
-\end{array}$ & $\begin{array}{r}13 \\
1 \\
0 \\
0\end{array}$ & $\begin{array}{l}9 \cdot 6 \\
4 \cdot 8 \\
-\end{array}$ & $\begin{array}{r}12 \\
2 \\
0 \\
0\end{array}$ & $\begin{array}{l}8 \cdot 8 \\
9 \cdot 5 \\
-\end{array}$ & $\begin{array}{r}136 \\
21 \\
9 \\
5\end{array}$ \\
\hline & & Total & $\cdots$ & 25 & $14 \cdot 6$ & 24 & $14 \cdot 0$ & 56 & $32 \cdot 7$ & 38 & $22 \cdot 2$ & 14 & $8 \cdot 2$ & 14 & $8 \cdot 2$ & 171 \\
\hline \multirow[t]{2}{*}{ Other } & \multirow[t]{2}{*}{$\cdots$} & $\begin{array}{l}<40 \\
<40 \\
40+ \\
40+\end{array}$ & $\begin{array}{l}\mathbf{S} \\
\mathbf{M} \\
\mathbf{S} \\
\mathbf{M}\end{array}$ & $\begin{array}{l}31 \\
15 \\
13 \\
41\end{array}$ & $\begin{array}{l}14 \cdot 2 \\
11.4 \\
16 \cdot 7 \\
20.8\end{array}$ & $\begin{array}{l}48 \\
38 \\
25 \\
59\end{array}$ & $\begin{array}{l}21 \cdot 9 \\
29 \cdot 0 \\
32 \cdot 1 \\
29 \cdot 9\end{array}$ & $\begin{array}{l}62 \\
39 \\
26 \\
61\end{array}$ & $\begin{array}{l}28 \cdot 3 \\
29 \cdot 8 \\
33 \cdot 3 \\
31 \cdot 0\end{array}$ & $\begin{array}{r}42 \\
19 \\
6 \\
9\end{array}$ & $\begin{array}{r}19 \cdot 2 \\
14 \cdot 5 \\
7 \cdot 7 \\
4 \cdot 6\end{array}$ & $\begin{array}{r}13 \\
3 \\
5 \\
12\end{array}$ & $\begin{array}{l}5 \cdot 9 \\
2 \cdot 3 \\
6 \cdot 4 \\
6 \cdot 1\end{array}$ & $\begin{array}{r}23 \\
17 \\
3 \\
15\end{array}$ & $\begin{array}{r}10.5 \\
13.0 \\
3.8 \\
7.6\end{array}$ & $\begin{array}{r}219 \\
131 \\
78 \\
197\end{array}$ \\
\hline & & Total & $\ldots$ & 100 & $16 \cdot 0$ & 170 & $27 \cdot 2$ & 188 & $30 \cdot 1$ & 76 & $12 \cdot 2$ & 33 & $5 \cdot 3$ & 58 & $9 \cdot 3$ & 625 \\
\hline
\end{tabular}

* $\mathbf{S}=$ single. $\quad \mathbf{M}=$ married, widowed and divorced.

Students are excluded, and eighteen patients of central 444 type are omitted. 
significant variation was found with social class. More muscular type $\mathrm{Ml}$ men were found in semiskilled and unskilled occupations, more types $\mathrm{Fl}$ and $\mathbf{L f}$ in the professions.

Although the higher order interactions between the variables measured must remain obscure, the relationships between phenotype dominance and diagnosis are straightforward if social class is ignored. The main contribution to significant variation comes from sector Lf, where there are nearly twice as many schizophrenics and only 60 per cent. as many depressives as might be expected. Depression was commoner than expected in types Mf and Fm. Lastly, disorders of character, behaviour and intelligence were commonest in type Ml.

It is clear that studies of the height and weight of different groups in the population are insufficient to indicate the very considerable variations of physique which govern selection for and the effects of employment in particular jobs. Measurements of fat and bone and muscle development are needed to facilitate interpretation. Constitutional factors of major im- portance are excluded if height and weight are the only measurements taken.

We wish to thank Mrs. T. Hazlewood and Mrs. D. M. Carne for statistical assistance. Beside our debt to Dr. Skottowe, already mentioned, we acknowledge the help of the medical superintendents of the St. John's, Fair Mile, Littlemore, and Warneford Hospitals in allowing patients under their care to be measured as part of a general survey of adults admitted to mental hospitals.

\section{REFERENCES}

Acheson, R. M. (1961). Brit. J. prev. soc. Med., 15, 49.

Davidson, M. A., Lee, D., Parnell, R. W., and Spencer, S. J. G. (1955). J. ment. Sci., 101, 810.

Heady, J. A., Morris, J. N., Kagan, A., and Raffle. P. A. B. (1961). Brit. J. prev. soc. Med., 15, 143.

Parnell, R. W. (1954). J. Hyg. (Lond.), 52, 369.

(1958). "Behaviour and Physique". Arnold, London. Registrar General (1958). "Statistical Review of England and Wales for the years 1952-53". Supplement on Mental Health. H.M.S.O., London.

Sheldon, W. H., Stevens, S. S., and Tucker, W. B. (1940). "The Varieties of Human Physique". Harper, New York. 